\title{
Monitoring of organic and inorganic nitrogen sources for the nitrogen nutrition of winter wheat using a chlorophyll meter (N-Tester $\left.{ }^{\circledR}\right)$
}

\author{
G Meade, T McCabe
}

University College Dublin, Lyons Research Farm, Newcastle, Co. Dublin, Ireland

Email: grainne.meade@gmail.com

Introduction Biomass production of crops is a function of nitrogen $(\mathrm{N})$ content in the plant (Lemaire et al., 2005). The $\mathrm{N}$ content of plants is highest at early growth stages and decreases continually up to the stage of senescence (Mistele \& Schmidhalter, 2008). Nitrogen is applied to crops in two main forms, organic manures (e.g. pig manures) or inorganic manures (e.g. calcium ammonium nitrate (CAN)). It is difficult for farmers to assess the available $\mathrm{N}$ in organic manures and their perception of its value is poor. Simple hand-held optical analysis methods like the Yara N-Tester ${ }^{\circledR}$ which measures leaf chlorophyll content could be used to quickly and accurately assess the N\% of a crop. The N-tester gives a dimensionless value which is proportional to the total value of chlorophyll, which can then be correlated to the $\mathrm{N}$ content of the plant. In this trial the N-Tester ${ }^{\circledR}$ method was used to monitor crop nitrogen uptake in trials comparing chemical fertiliser (CF) and separated liquid pig manure (LPM) as crop $\mathrm{N}$ sources for winter wheat.

Materials and methods Field experiments were carried out on a winter wheat crop cv. Einstein in 2009 at two sites Newcastle and Lyons. The Newcastle site was a clay loam $\mathrm{N}$ index 1 soil (continuous cereals), while Lyons was a clay loam, $\mathrm{N}$ index 2 soil (after 3 years ley). The crops were sown in mid-October with mid-September harvest dates. The trials were laid out in a randomised complete block design with four replicates in a factorial arrangement with two factors $-\mathrm{N}$ source and $\mathrm{N}$ application timing (Table 1). Pig manure treatments received 30,000 1/ha (120kgN/ha) of LPM and CF treatments received $120 \mathrm{kgN} /$ ha supplied as calcium ammonium nitrate (CAN 27\% N). Post N application N-Tester $\mathbb{R}$ measurements were taken at 10 day intervals until natural senescence occurred consisting of 30 leaf readings per plot $\left(1.6 \mathrm{~m}^{*} 12 \mathrm{~m}\right)$. The N-tester uses light transmission at two wavelengths (650nm and 960nm) to quickly assess chlorophyll content. Optical analysis methods such as the N-Tester ${ }^{\circledR}$ offers advantages over traditional plant sampling techniques as it is a rapid in-crop method which is non-destructive.

Table 1 Trial treatments and N-Tester® chlorophyll unit readings (average site $1 \& 2$ ANOVA).

\begin{tabular}{|c|c|c|c|c|c|c|c|c|}
\hline \multirow{2}{*}{$\begin{array}{l}\text { Days (d) post } \\
\text { Application }\end{array}$} & \multicolumn{4}{|c|}{ N Source } & \multicolumn{4}{|c|}{ Application Timing } \\
\hline & $\mathrm{CF}$ & LPM & Untreated & L.S.D & GS 30-31 & GS 35 & GS 37-39 & L.S.D \\
\hline$+10 \mathrm{~d}$ & $554^{\mathrm{b}}$ & $572^{\mathrm{a}}$ & $471^{\mathrm{c}}$ & 11.56 & $557^{\mathrm{a}}$ & $516^{\mathrm{b}}$ & $524^{\mathrm{b}}$ & 11.56 \\
\hline$+20 \mathrm{~d}$ & $612^{\mathrm{a}}$ & $607^{\mathrm{a}}$ & $443^{b}$ & 14.25 & $567^{\mathrm{a}}$ & $551^{\mathrm{b}}$ & $544^{\mathrm{b}}$ & 14.24 \\
\hline$+30 \mathrm{~d}$ & $613^{\mathrm{a}}$ & $598^{\mathrm{a}}$ & $428^{b}$ & 24.42 & $562^{\mathrm{a}}$ & $551^{\mathrm{a}}$ & $526^{\mathrm{b}}$ & 24.42 \\
\hline$+40 \mathrm{~d}$ & $616^{\mathrm{a}}$ & $578^{\mathrm{b}}$ & $371^{\mathrm{c}}$ & 22.05 & $532^{\mathrm{a}}$ & $528^{\mathrm{a}}$ & $504^{\mathrm{b}}$ & 22.05 \\
\hline$+50 \mathrm{~d}$ & $575^{\mathrm{a}}$ & $520^{\mathrm{b}}$ & $313^{\mathrm{c}}$ & 19.46 & $512^{\mathrm{a}}$ & $507^{\mathrm{a}}$ & $389^{\mathrm{b}}$ & 19.46 \\
\hline$+60 d$ & $480^{\mathrm{a}}$ & $405^{\mathrm{b}}$ & $225^{\mathrm{c}}$ & 22.04 & $499^{\mathrm{a}}$ & $372^{\mathrm{b}}$ & $239^{c}$ & 22.04 \\
\hline$+70 \mathrm{~d}$ & $330^{\mathrm{a}}$ & $296^{\mathrm{b}}$ & $129^{c}$ & 19.48 & $384^{\mathrm{a}}$ & $233^{\mathrm{b}}$ & $138^{\mathrm{c}}$ & 19.48 \\
\hline Yield (t/ha) & $9.57^{\mathrm{a}}$ & $8.76^{\mathrm{b}}$ & $5.94^{\mathrm{c}}$ & 0.44 & $8.26^{\mathrm{a}}$ & $8.14^{\mathrm{a}}$ & $7.88^{\mathrm{a}}$ & 0.44 \\
\hline GNU (kgN/ha) & $85.00^{\mathrm{a}}$ & $78.66^{\mathrm{b}}$ & $52.91^{\mathrm{c}}$ & 5.84 & $73.51^{\mathrm{a}}$ & $71.82^{\mathrm{a}}$ & $71.23^{\mathrm{a}}$ & 5.84 \\
\hline
\end{tabular}

${ }^{*}$ Means with a common superscript are not significantly $(\mathrm{P}<0.05)$ different. LSD $=$ Least significant difference

Results Differences between N source treatments were visible within 10 days of application $(\mathrm{P}<0.0001)$ with the LPM treatment having higher chlorophyll unit readings (CU) than the CF treatment. As the LPM was applied in liquid form compared to granular $\mathrm{CF}, \mathrm{N}$ was more freely available for uptake in the days immediately after application. However, once $\mathrm{CF}$ became available for plant uptake CU increased. Until 30d post manure application the LPM and CF treatments were similar with the untreated treatments consistently showing reduced $\mathrm{CU}(\mathrm{P}<0.0001)$. However, from day 40-70 the $\mathrm{CF}$ treatment appeared greener and had higher $\mathrm{CU}(\mathrm{P}<0.05)$. The same trend is evident in grain yield and grain $\mathrm{N}$ uptake data with the CF significantly higher than both the LPM and control treatments $(\mathrm{P}<0.0001)$. Treatments receiving $\mathrm{N}$ at the earliest application timing (GS 30-31) had consistently higher CU than timings 2 and 3. At 30d post application date 1 and 2 were similar, however timing 3 was lower $(\mathrm{P}<0.02)$. Later applied $\mathrm{N}$ at GS 37-39 was not used to its full potential as evident from $\mathrm{CU}$ from $\mathrm{d} 50-70$ where a dramatic fall in $\mathrm{CU}$ indicates $\mathrm{N}$ deficiency in the crop and subsequent early senescence. This 100 unit fall occurred at d60 with timing 2 and not until d70 in timing 1 showing that a higher level of chlorophyll was present in the crop receiving $\mathrm{N}$ at an earlier growth stage.

Conclusion $\mathrm{N}$ application at earlier growth stages (GS 30-31) is more effective at increasing leaf chlorophyll content and therefore has a greater ability to influence crop yield. The N-Tester ${ }^{\circ}$ data indicates that N applied as LPM is more available to the crop the 10-20 days after application. However, the data from this study also indicates that the N in LPM is less utilised than CF 40-60 days after the initial application date. The N-Tester ${ }^{\circledR}$ is an effective tool in monitoring crop $\mathrm{N}$ status and as a research tool has the ability to separate subtle colour differences not visually apparent as observed between LPM and CF treatments in this study.

\section{References}

Lemaire, G., Avice, J.C., Kim, T.H \& Ourry, A. 2005. Journal of Experimental Botany 56, 935-943

Mistele, B. \& Schmidhalter, U. 2008. Field Crops Research 106, 94-103 